\title{
Chronic synovitis with early cartilage destruction in sickle cell disease
}

\author{
H. RALPH SCHUMACHER, BONNIE B. DORWART, JAMES BOND, ABASS ALAVI, \\ AND WALLACE MILLER \\ From the Department of Medicine and Radiology, Hospital of the University of Pennyslvania and Veterans \\ Administration Hospital, Philadelphia
}

SUMmaRY Two patients with sickle cell disease presented with joint pain and early $x$-ray evidence of articular cartilage loss. Both later developed increasingly destructive arthritis with chronic synovitis identified in synovial biopsies. One patient developed demonstrable aseptic necrosis. Destructive arthropathy is much less common than the frequent transient effusions in sickle cell disease.

The most common arthropathy in sickle cell disease has consisted of transient noninflammatory effusions. These are often associated with crises and are suspected to be a result of microvascular occlusion in synovial, bone, or other periarticular tissues (Schumacher et al., 1973). Some joint effusions however are 'inflammatory' with leucocyte counts from $33000-176000 / \mathrm{mm}^{3}\left(33-176 \times 10^{9} / \mathrm{l}\right)$ (Goldberg, 1973; Orozco-Alcala and Baum, 1973; Hanissian and Silverman, 1974). Such inflammatory effusions with negative cultures and without demonstrable crystals remain unexplained. Joint destructive changes when reported in sickle cell patients have been a result of antecedent deformity of aseptic necrosis or infection (Schumacher et al., 1973). We describe 2 patients in whom, although no effusions were studied, there was destructive arthritis with a dramatic early loss of articular cartilage. Surgical exploration in both cases showed a chronic synovitis that presumably is, though still undetermined, a result of sickle cell disease.

\section{Case reports}

CASE 1

A 19-year-old housewife had been diagnosed as having sickle cell disease at age 3 during an evaluation for abdominal pain. She had many subsequent crises with fever and abdominal pain. In 1972 she presented with a 2-day history of left elbow pain and a warm, tender swollen elbow joint. Synovial fluid was aspirated and was slightly cloudy with two

Accepted for publication February 23, 1977

Correspondence to Dr. H. Ralph Schumacher, V.A. Hospital, Philadelphia, Pennsylvania 19104, U.S.A. leucocyte counts in different laboratories reported as 0.6 and $14.0 \times 10^{9}$ cells $/ 1$. Cultures were negative and synovial fluid glucose was $5.6 \mathrm{mmol} / \mathrm{l}(100$ $\mathrm{mg} / 100 \mathrm{ml}) . X$-rays were normal. Serum rheumatoid factor was positive with a titre of 1:160; ESR was $67 \mathrm{~mm} / \mathrm{h}$. Irregular boney sclerosis was present in the spine and ribs. In late 1972 she had an aplastic crisis. In early March 1973 in the absence of fever or other symptoms she noted the sudden onset of warmth, tenderness, and pain on motion at the left wrist, though only swelling was present when she was first examined on 20 March 1973. $X$-rays showed navicular cysts and osteopenia (Fig. 1a). A left wrist splint and aspirin 15 grains four times daily gave no relief. On 14 May 1973, the left wrist was definitely swollen on both the dorsal and volar aspects.

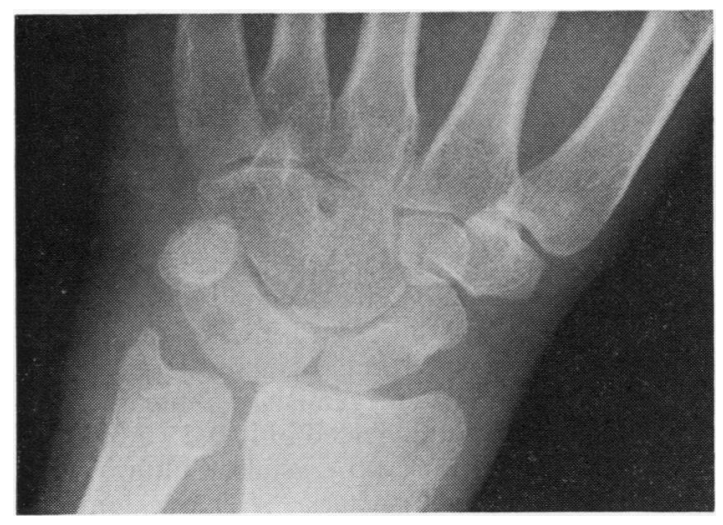

$1(a)$ 

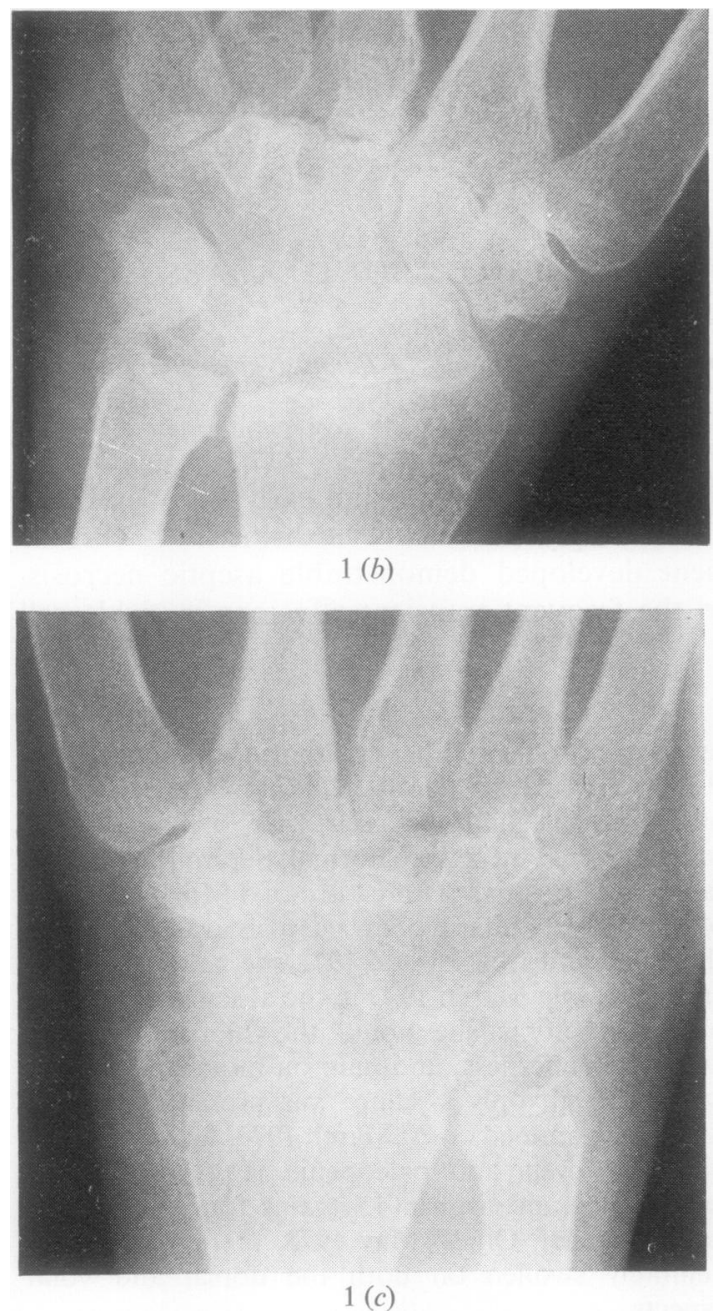

Fig. 1 (a) Wrist X-ray of Case 1 in March 1973, 2 weeks after onset of wrist pain and swelling. There are carpal cysts and some osteopenia, but the joint spaces (cartilage) are well preserved. (b) Wrist $\mathrm{x}$-ray in November 1973 with cartilage destruction shown by narrowing of radiocarpal and intercarpal joint spaces. (c) Early 1974 wrist $\mathrm{x}$-ray, showing further cartilage destruction and now erosion in subchondral bone.

Technetium sulphur colloid marrow scan was normal and bone scan using technetium polyphosphate showed slightly increased uptake around the left wrist which was interpreted as indicating reactive bone formation and hyperaemia. In September the wrist was aspirated and yielded only $0.25 \mathrm{ml}$ bloodtinged fluid. There were no crystals. Cultures were negative for routine bacteria, Neisseria, mycobacteria, and fungi. By 22 October, wrist motion was limited to $15^{\circ}$ because of pain and swelling There was slight painless swelling at the right, third metacarpophalangeal (MCP) joint. Rheumato factor, LE prep, and VDRL were negative. $X$-ra跨 now showed narrowing of radiocarpal and intes. carpal joints (Fig. 1b). On 12 November 197\% Parker-Pearson needle synovial biopsy of the wriegt was attempted after aspiration yielded no joint fluifi The small piece of synovium was normal except fớ a clump of lymphocytes around one small vessed Triamcinolone hexacetonide was injected into the wrist with some reduction in swelling but the sever pain persisted. Immobilization of the wrist in splint for 6 weeks gave no relief.

Haemoglobin ranged from 8-9 g/dl; Hb electro phoresis showed $70 \% \mathrm{HbS}, 6 \% \mathrm{HbA}_{2}$, and $24 \%$ fetal $\mathrm{Hb}$. Plasma urate was $0.23 \mathrm{mmol} / 1 \mathrm{(3.8)}$ $\mathrm{mg} / 100 \mathrm{ml}$ ). The spleen was palpable. Her parents were deceased, making further genetic studies impossible. It was felt that the patient most like had a sickle-thalassaemia. $X$-rays in early $19 \mathrm{k}$ showed further carpal destructive change (Fig. 10

In March 1974, she was admitted for exploration of the left wrist. Her right third MCP was swolletib and tender; the left wrist was very painful and movement limited to about $5^{\circ}$ flexion and swolle The right elbow and all other joints were norma She had no nodules. There was a grade 3 systolie murmur at the left lower sternal border. She wa transfused with 2 units of packed red cells and the left wrist was explored without a tourniquet. The synovium was grossly congested and proliferater with focal haemorrhages of the synovium of carp joints, wrists, and tendon sheaths. Wrist cartilage was thinned. No pannus was identified. Arthrodesis of the wrist was performed with a bone graft from the iliac crest.

Histopathological examination of the synoviun showed vascular congestion, many extravasated rè cells, large clusters of lymphocytes, and plasma ce in the deep synovium (Fig. 2), some plasma celfs with Russell bodies, a single layer of synovial lining cells, perivascular haemosiderin deposits, some sm vessels with collapsed or thrombosed lumens, an perivascular fibrosis. Cultures of the synovium we negative for routine bacteria, anaerobes, Neisserio tuberculosis, and fungi. A specimen fixed in absolu alcohol showed no crystals. There was fibrillation of the surface cartilage.

The wrist healed after the fusion and there was pain despite the inability to remove all the prolife. ated synovium. She had not been using more than 10 grains of aspirin three times a day. Rheumatoji factor was again negative and Westergren ES $12 \mathrm{~mm} / \mathrm{h}$.

In early 1975 pain and swelling gradually beg角 


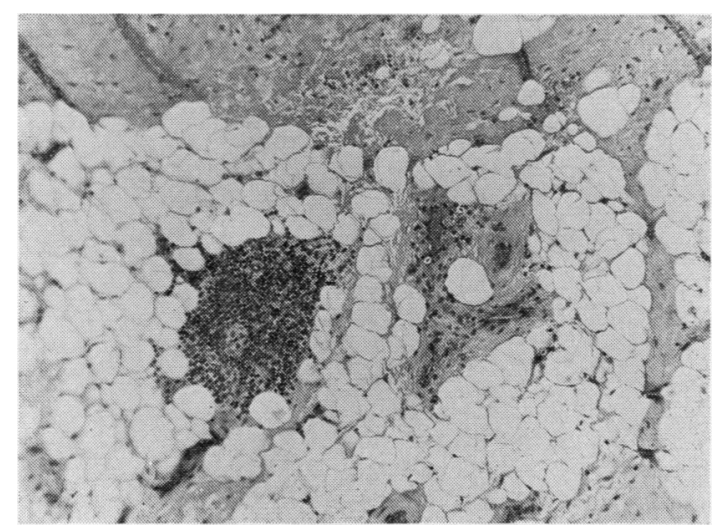

Fig. 2 Case 1. Intense chronic inflammatory cell infiltration in the deep synovium. Haematoxylin and eosin. $\times 50$.

in the right wrist. She required further admissions for painful crises none of which were accompanied by joint effusions. In September 1975, she was hospitalized for fusion of the right wrist. The wrist was tender and swollen with crepitus and total flexion-extension of only $30^{\circ}$. The left wrist had no pain and no swelling but some right 3rd MCP swelling and tenderness persisted. Latex fixation, LE prep, Coombs's test, VDRL, cryoglobulins, urinalysis, and blood urea nitrogen were negative or normal. A fluorescent antinuclear factor was positive at 1:10 with a diffuse pattern; haematocrit was $30 \%$, and gammaglobulin $21.7 \mathrm{~g} / 1$ on protein electrophoresis. There were many target cells and few sickle forms on her peripheral blood smear.

A right wrist fusion was performed using a left iliac crest bone graft. A tourniquet was used without complications. There was no operative description available except for the impression of 'synovial oedema without pannus or induration as seen in rheumatoid arthritis'. Light microscope examination of the synovial membrane identified normal lining cells, vascular congestion, occasional perivascular fibrosis, scattered haemosiderin, and clumps of plasma cells with occasional lymphocytes. The cartilage surface was fibrillated with no other demonstrable changes.

Electron microscope study of synovial membrane from both wrist specimens confirmed the light microscope findings with lymphocyte and plasma cell infiltration and also showed extravasated erythrocytes with some erythrophagocytosis. Venule walls had prominent endothelium with some gaps between endothelial cells. Neither sickled erythrocytes nor electron-dense deposits in vessel walls were seen. There were rare necrotic synovial cells. She did well postoperatively, and when last seen for chest and back pain in November 1976 had no joint swelling. Both wrists were fused and painless. The right 3rd MCP had slight crepitus but no swelling or tenderness. The spleen was still palpable. Haematocrit was $26 \%$; antinuclear factor and latex fixation were negative.

CASE 2

A 33-year-old man had a history of multiple crises with abdominal and extremity pain, pulmonary infarctions, repeated pneumococcal pneumonia, retinal vascular occlusions, and a cerebral vascular accident. Haemoglobin electrophoresis had shown $96.2 \% \mathrm{HbS}$, and $3.8 \% \mathrm{HbA}_{2}$. $\mathrm{Hb}$ levels ranged between 8.6 and $10.5 \mathrm{~g} / \mathrm{dl}$ with $4-13 \%$ reticulocytes. The patient was also a heavy drinker, taking a pint of wine and 4-5 beers per day.

Five days before admission on 26 March 1969, he developed a runny nose and on the day of admission severe pain in the lower back, right hip, right knee, and chest. Blood pressure was $150 / 85 \mathrm{mmHg}$. Temperature rose to $104^{\circ}$, pulse 110 . He had tenderness around the lower back and right pelvis but no joint effusions. Right hip motion was limited by pain. $\mathrm{Hb}$ was $8.8 \mathrm{~g} / \mathrm{dl}$; plasma bilirubin rose from 55 to $310 \mu \mathrm{mol} / \mathrm{l}(3 \cdot 2-18 \mathrm{mg} / 100 \mathrm{ml})$; SGOT $250 \mathrm{IU}$;

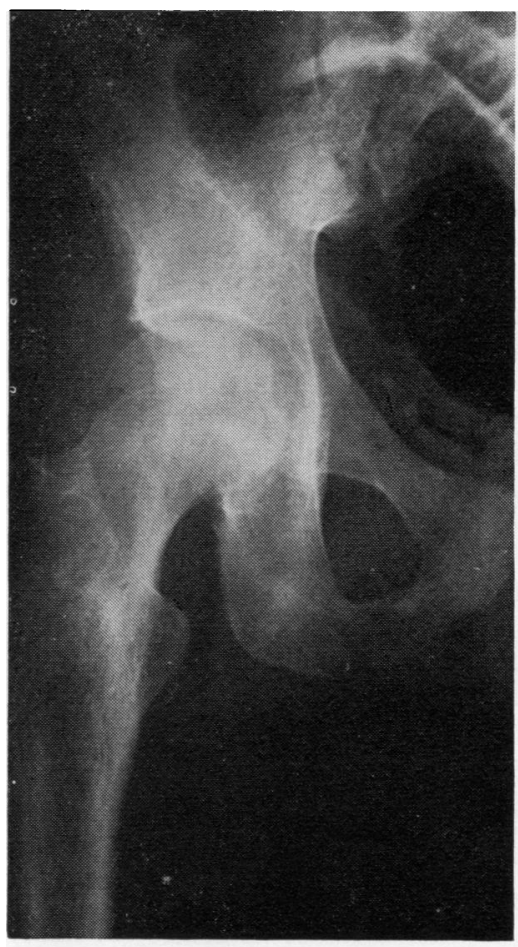

$3(a)$ 


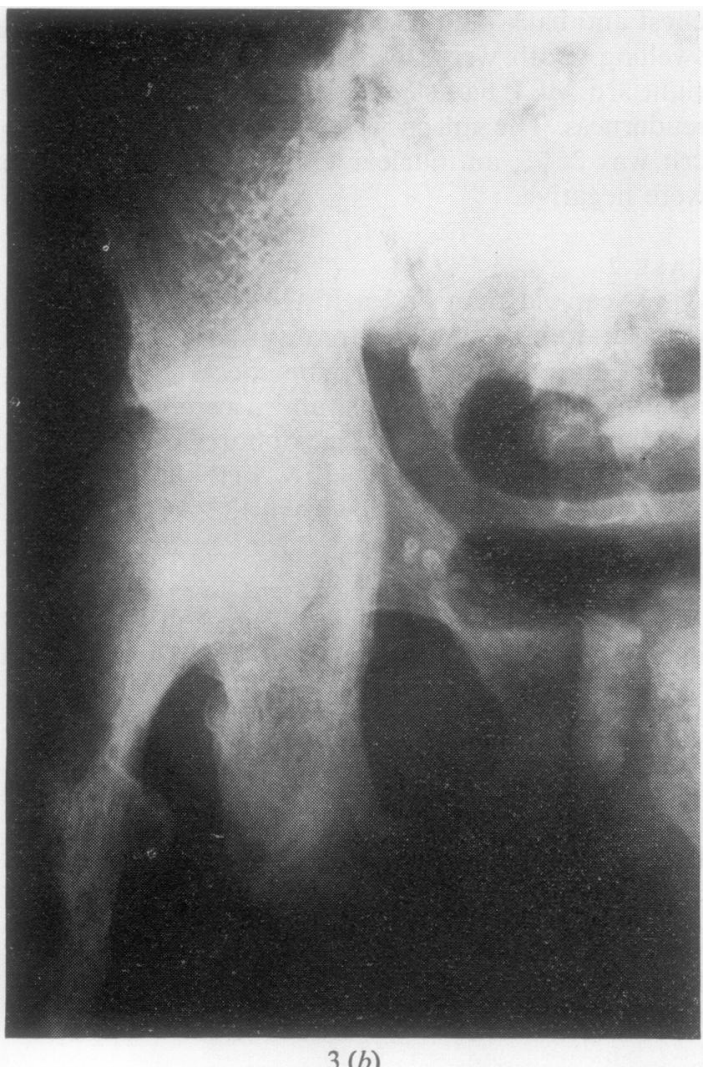

SGPT $230 \mathrm{IU}$; plasma urate $0 \cdot 25 \mathrm{mmol} / \mathbf{1}(\mathbf{4} \cdot 2$ $\mathrm{mg} / 100 \mathrm{ml}) .15$ blood cultures were all negative and he remained febrile despite a course of intravenous penicillin. On the third hospital day his platelet count had fallen to $49 \times 10^{9} / 1$; Hb was $7.0 \mathrm{~g} / \mathrm{dl}$; up to $53 \%$ nucleated RBCs were found in the peripheral blood along with 1-2\% myeloblasts. Bone marrow aspirates showed necrotic marrow from 4 sites. $X$-rays showed widespread patches of bone lucency or increased density, increased trabecular marking, and periosteal elevation in the spine, pelvis, skull, and humerus. The right hip joint and femoral head were normal (Fig. 3a).

Treatment included analgesics and transfusions with packed red cells. $\mathrm{Hb}$ gradually fell to $8 \cdot 5-9 \cdot 5$ $\mathrm{g} / \mathrm{dl}$ and platelets rose to $500 \times 10^{9} / 1$. One month after admission marrow aspirated from the sternum grew an anaerobic streptococcus and a course of ampicillin $12 \mathrm{~g} /$ day IV was given. In August right hip $x$-rays showed mild joint-space narrowing (Fig. $3 b$ ) which had progressed one month later though with good preservation of the shape of the femoral head (Fig. 3c). Diffuse increase in density of many bones including the femoral heads was noted.

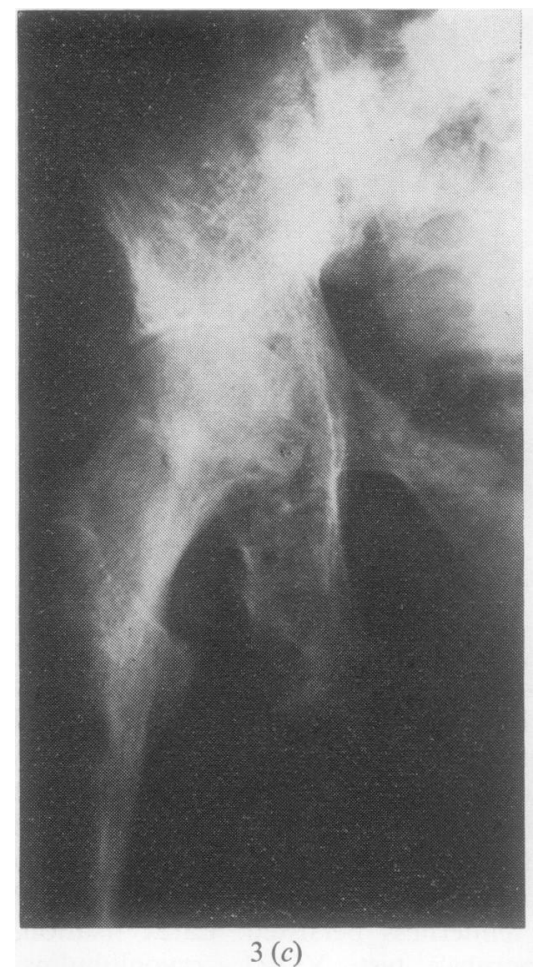

During his hospital stay he lost a total of 5 inch in height due largely to massive destruction of vertebrae. He was discharged after a total of $\overrightarrow{\partial 6}$ months of hospitalization. As an outpatient he was well except for increasing right hip pain on walkin with 30 minutes of morning stiffness at the hip. Fe had no fever. He required a cane and six $65 \mathrm{mgg}$ propoxyphene capsules per day.

In October 1970 he had a $30^{\circ}$ flexion contracture at the right hip and no rotation. $X$-rays now showed erosion of both femoral and acetabular surface sclerosis, and some flattening of the femoral head (Fig. 3d). The right hip was aspirated yielding bloodtinged fluid with sickled erythrocytes, $0.060 \times 17^{\circ}$ WBC/ 1 and negative cultures. Westergren ESR wïs $6 \mathrm{~mm} / \mathrm{h}$; plasma urate $0.42 \mathrm{mmol} / 1(7.06 \mathrm{mg} / 109)$ $\mathrm{ml})$; plasma calcium $2.36 \mathrm{mmol} / \mathrm{l}(9 \cdot 44 \mathrm{mg} / 100 \mathrm{ml}) ;$ SGOT $80 \mathrm{IU}$. He was given preoperative transfusi@ to $\mathrm{Hb}$ level of $10 \mathrm{~g} / \mathrm{dl}$ and on 17 November $1970 \mathrm{had}$ a right hip exploration. Routine fungus and tuberculosis cultures obtained from the synovium at surgery were all negative. Collapse of the femong head and virtual complete absence of cartilage on the femoral head were noted.

A Weber-Tronzo total hip prosthesis was insertę․ He had an uneventful convalescence. The femolal head showed necrotic bone with loss of maify 


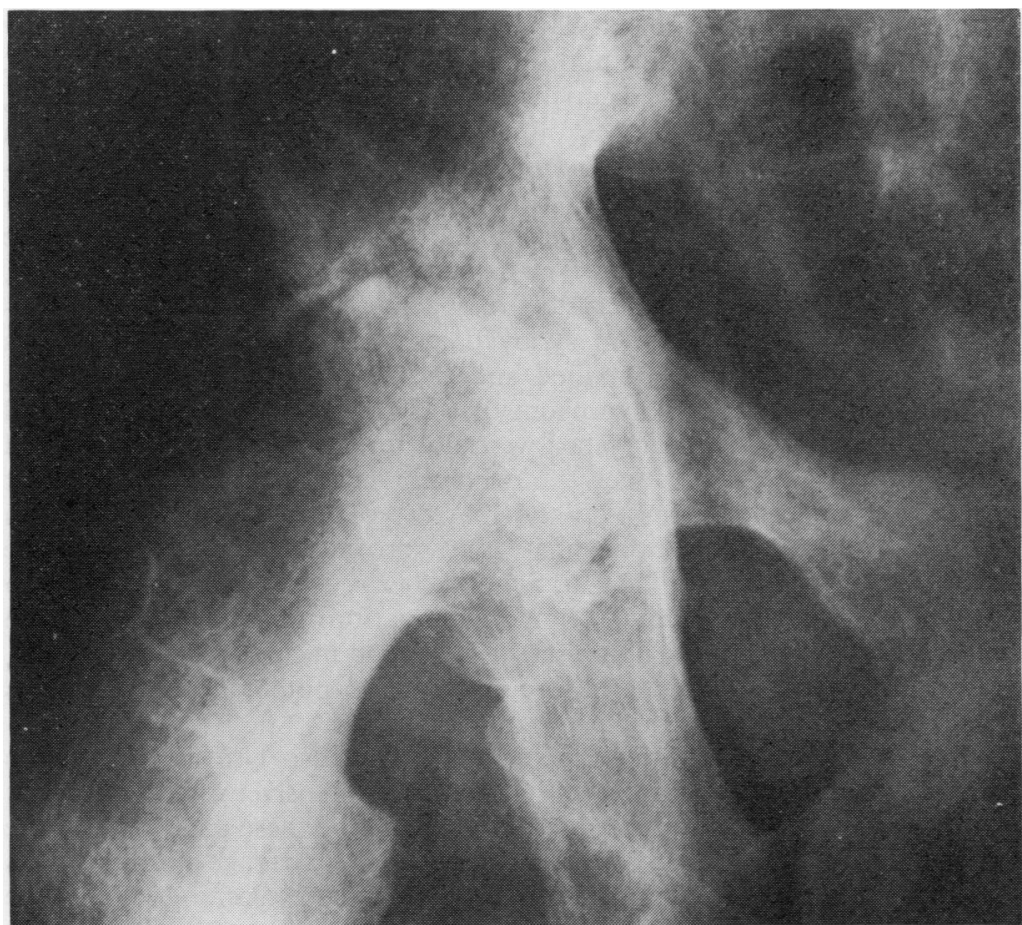

Fig. 3 (a) Right hip x-ray of Case 2 showing normal femoral head and no joint-space narrowing at the time of admission with right hip pain and documented bone infarctions elsewhere. (b) 5 months after the initial hip x-ray there is joint-space narrowing and diffuse increased density of bones including the femoral head but still intact femoral head shape. (c) One month later joint-space narrowing is more pronounced, definite increased bone density persists, but there is no evidence of collapse of femoral head bone. (d) 14 months after the initial hip $\mathrm{x}$-ray there are now subchondral destructive changes in both acetabulum and femoral head.

osteocytes, granulation tissue, and masses of plasma cells in the marrow. Giant cells were also seen in this inflammatory tissue. One such cell contained tiny birefringent chunks in the cytoplasm. A single positively birefringent rhomboid-shaped crystal was seen near this giant cell. Many fragments of necrotic bone were also found. Synovium obtained at hip surgery showed mostly normal synovial lining cells but with focal increases up to 4 layers deep. There were prominent villi and mostly fibrous synovium.

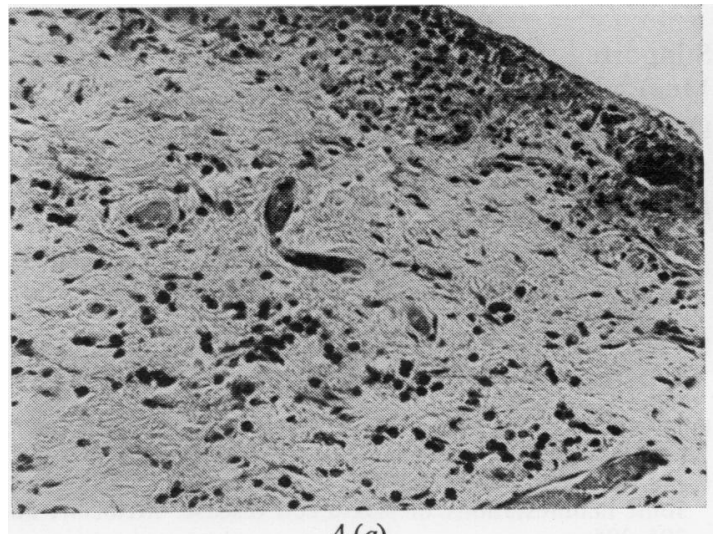

$4(a)$
Vessels seen were patent but many extravasated erythrocytes were scattered through the synovium; there was perivascular haemosiderin deposition. Most dramatic was the intense diffuse and perivascular infiltration with plasma cells and lymphocytes (Fig. 4).

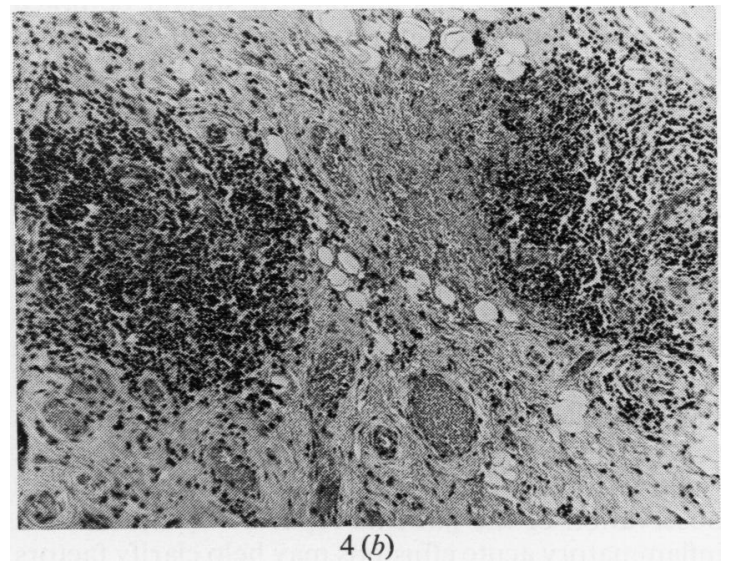

Fig. 4 (a) Synovium from Case 2 showing mildly hyperplastic lining cell layer and scattered deep mononuclear cells. Haematoxylin and eosin. $\times 100$. (b) Intense deep chronic inflammatory cell infiltration in the same synovium. Haematoxylin and eosin. $\times 50$. 
He had no further peripheral joint problems although chronic back pain continued and he had many admissions for painful crises. In 1974 and 1975 latex fixation tests and antinuclear factor were negative. In 1974 he developed chronic myelogenous leukemia and in late 1975 developed a blastic crisis and died despite therapy with vinblastine and prednisone.

\section{Discussion}

These 2 patients with sickle-thalassaemia and homozyous sickle cell disease, in contrast to most patients with articular problems in sickle cell disease, had a chronic synovitis with profuse plasma cell infiltration and evidence of cartilage loss as an early radiographic manifestation.

Synovium in both cases, despite showing dramatic chronic inflammatory cell infiltration, did not have other features such as fibrin deposition, synovial necrosis, and lining cell proliferation of the degree seen in rheumatoid arthritis (Ropes et al., 1958). Such chronic inflammation has not been described in most previous studies of bone, joints, or other sites in sickle cell disease (Schumacher et al., 1973; Diggs and Ching, 1934). Espinoza et al. (1974) did find plasma cells in one synovium in an acute arthritis. Sherman (1959), in a sickle cell patient with aseptic necrosis, found some chronic inflammation and speculated on the possible role of pannus. Fink (1968) also noted some plasma cells around conjunctival vessels in sickle cell patients. Thus, chronic inflammation is a possible factor in the cartilage damage.

Such inflammation must suggest consideration of immunological factors although it should be noted that some lymphocyte and plasma cell infiltration seems to be purely a secondary result of apparently 'nonimmunological disease' such as gout (Agudelo and Schumacher, 1973). Evidence for immunological alterations in sickle cell disease is still scanty but includes glomerular disease thought to be due to immune complexes (Walker et al., 1971; Strauss et al., 1974) and a deficiency demonstrable in the properdin system (Johnston et al., 1973). Case 1 has had on separate occasions both a weakly positive latex fixation test and antinuclear factor. At no time has she fulfilled criteria for either 'definite' rheumatoid arthritis or systemic lupus erythematosus. Careful follow-up is being continued. Further observation of the patients reported by others with inflammatory acute effusions may help clarify factors leading to the unexplained inflammation.

A further possible explanation for acute or chronic arthritis in sickle cell disease is gouty arthritis (Schumacher et al., 1973). Although it has been stated that crystals were not found in most cases reported with inflammatory effusions, crystals maly be few and difficult to identify even in typical gout. In one patient reported elsewhere (Schumacher et $\overrightarrow{\mathrm{F}}$.). 1975) we found no crystals on a long search of 3 n acute inflammatory effusion by compensated polarized light but easily identified huge numbers $\overline{\bar{n}}$ of crystals from fluid aspirated from the same joint 角e next day. The explanation for this is not yet known. Urate crystals may also be very difficult to demenstrate in synovial membrane unless large biopsies are obtained and the tissue is handled in alcohol. The synovium of Case 1 was processed in alcolol and crystals were not found. The rhomboid-shaped positively birefringent crystal and birefringent chunks in the marrow of Case 2 suggest calcium pyrophosphate or hydroxyapatite crystals (Diepłpe et al., 1976; Schumacher et al., 1976) which can also produce joint inflammation. Crystals were so răgre and no crystals were found in cartilage or synovium, but perhaps crystals could potentiate other factors contributing to joint disease.

Infection of course can also lyse cartilage. TT was considered and was intensively sought but demonstrated in the joints of these patients. Aseptic necrosis causing secondary cartilage destruction is common in sickle cell disease (Jaffe, 1969). Some early necrosis of femoral head bone was detected by increased bone density in Case 2 but the seque ace of definite joint-space narrowing before any evide $\overline{c c}$ of femoral head collapse is not what is expected wh the usual aseptic necrosis. If bone necrosis adjacent to the joint is a factor in initiating the synovitis $\overrightarrow{\text { बin }} \mathrm{d}$ cartilage lysis by mechanisms other than distortion of the femoral head, these mechanisms are not clear. In osteonecrosis of femoral condyles there.is a report of calcium pryophosphate crystals in associated knee effusions (Houpt and Sinclair, 19.95) so that crystal-induced inflammation might be a basis for changes in joints adjacent to areas of bene necrosis.

Supported in part by a grant from the Barsumian Memorial Fund and US Veterans Administration grant no. 103.13M.

\section{References}

Agudelo, C. A., and Schumacher, H. R. (1973). The synovilis of acute gouty arthritis. A light and electron microscepic study. Human Pathology, 4, 265-279.

Dieppe, P. A., Crocker, P., Huskisson, E. C., and Willough D.A. (1976). Apatite deposition disease. A new arthropathy. Lancet, 1, 266-269.

Diggs, L. W., and Ching, R. E. (1934). Pathology of sickle cell anemia. Southern Medical Journal, 27, 839-845.

Espinoza, L. R., Spilberg, I., and Osterland, C. K. (19 $\overrightarrow{\mathrm{g}})$ Joint manifestations of sickle cell disease. Medicine, $\frac{7}{8}$ 295-305. 
Fink, A. I. (1968). Vascular changes in the bulbar conjunctiva associated with sickle cell disease: some observations on fine structure. Transactions of the American Ophthalmological Society, 66, 788-826.

Goldberg, M. A. (1973). Sickle cell arthropathy. Analysis of synovial fluid in sickle cell anemia with joint effusion. Southern Medical Journal, 66, 956-958.

Hanissian, A. S., and Silverman, A. (1974). Arthritis of sickle cell anemia. Southern Medical Journal, 67, 28-32.

Houpt, J. B., and Sinclair, D. S. (1975). Spontaneous osteonecrosis of the median femoral condyle. (Abst.) Journal of Rheumatology, 1, Suppl. 1, 117.

Jaffe, H. L. (1969). Skeletal manifestations of sickle cell anemia and sicklemia. Medical Radiography and Photography, 45, 76-86.

Johnston, R. B., Newman, S. L., and Struth, A. G. (1973). An abnormality of the alternate pathway of complement activation in sickle cell disease. New England Journal of Medicine, 288, 803-808.

Orozco-Alcala, J., and Baum, J. (1973). Arthritis during sickle cell crisis. (Letter.) New England Journal of Medicine, 288, 420.

Ropes, M. W., Bennett, G. A., Cobb, S., Jacox, R., and Jessar, R. A. (1958). 1958 Revision of diagnostic criteria for rheumatoid arthritis. Bulletin on Rheumatic Diseases' 9, 175-176.

Schumacher, H. R., Andrews, R., and McLaughlin, G. (1973). Arthropathy in sickle cell disease. Annals of Internal Medicine, 78, 203-211.

Schumacher, H. R., Jimenez, S. A., Gibson, T., Pascual, E., Traycoff, R. B., Dorwart, B. B., and Reginato, A. J. (1975). Acuty gouty arthritis without urate crystals identified on initial examination of synovial fluid. Arthritis and Rheumatism, 18, 603-612.

Schumacher, H. R., Tse, R., Reginato, A. J., Miller, J., and Maurer, K. (1976). Hydroxyapatite-like crystals in synovial fluid cell vacuoles. A suspected new cause for crystal induced arthritis. (Abst.) Arthritis and Rheumatism, $19,821$.

Sherman, M. (1959). Pathogenesis of disintegration of the hip in sickle cell anemia. Southern Medical Journal, 52, 632-637.

Strauss, J., Koss, M., Griswold, W., Chernack, W., Pardo, V., and McIntosh, R. M. (1974). Cryoprecipitible immune complexes, nephropathy and sickle cell disease. (Letter.) Annals of Internal Medicine, 81, 114.

Walker, B. R., Alexander, R., Birdsall, T. R., and Warren, R. L. (1971). Glomerular lesions in sickle cell nephropathy. Journal of the American Medical Association, 215, 437-440 